Environment Conservation Journal 14(3) 183-186, 2013

ISSN 0972-3099 (Print) 2278-5124 (Online)

Abstracted and Indexed

\title{
Physico-chemical study of Moghat Reservoir at Khandwa, Madhya Pradesh
}

\section{Shail Joshi}

Received: 08.08.2013
Revised: 16.09.2013

Accepted: 22.10.2013

\begin{abstract}
The present study has been carried out on Moghat Reservoir situated at Khandwa District of Madhya Pradesh. In the present study, the water samples were analyzed for various physico-chemical parameters like temperature,transparency, turbidity, TDS, pH, Free $\mathrm{CO}_{2}$, total hardness, Ca hardness, Mg hardness, DO, BOD and COD on two different sites of the reservoir. During the course of study value of DO fluctuated between $6.04 \mathrm{mg} / \mathrm{l} \mathrm{to} 8.58 \mathrm{mg} / \mathrm{l}$. Value of BOD and COD fluctuated from $0.98 \mathrm{mg} / \mathrm{l}$ to $3.51 \mathrm{mg} / \mathrm{l}$ and $9.0 \mathrm{mg} / \mathrm{l}$ to $12.3 \mathrm{mg} / \mathrm{l}$ respctively. It was found that around all the parameters were more or less similar at both the sampling stations. The water quality was found suitable but it is strongly recommended that regular monitoring of the Moghat reservoir at Khandwa is very important as it is the major source of freshwater. Thus it is apparent that much attention should be paid on further studies of the physico-chemical and biological parameters of the Moghat reservoir
\end{abstract}

Keywords:

\section{Introduction}

The lake and reservoirs containing fresh water are used for fish culture, aquaculture, navigation and transport, recreation, irrigation hydropower generation and a host of such other purposes. They are also the sources of water for drinking, household and industrial requirements. They serve as the most convenient and cheapest refuse dumping places for domestic and industrial wastes. So water bodies are heated, polluted and excessively fertilized. The fresh water is becoming rare day by day as civilization draws nearer. Its quality has also equally deteriorated. Now man started realizing the effect of this pollution problem and trying to improve the quality of the water to reuse the same.Aquatic life is influenced directly or indirectly by the physical, chemical and biological factors, fluctuation in any one of the factors may create an adverse environment to the organisms, affecting their growth and life phenomena. All the hydrobiologists have established these facts.The present study has been carried out in Moghat reservoir which is located 3 kilometer away from the Khandwa city in northwest. The geographic position of this reservoir is $21-49^{\prime} \mathrm{N}$ and $76-20$ ' E. It is situated $1071 \mathrm{ft}$. above from mean sea level. The surface area of the reservoir is $2.02 \mathrm{sq}$. Km

\section{Author's Address}

Department of Zoology, Govt. P.G. College, Khargone

Email: joshizoology@gmail.com with the maximum depth $5.2 \mathrm{~m}$. and mean depth $1.2 \mathrm{~m}$. it has 5.36 kilometer long shoreline. No known source of pollution is there. Only rainwater brings the dead organic matter and some agricultural effluents from its catchments area.

\section{Material and methods}

For present study of the Paniyala pond, the water samples were collected monthly from four different sampling sites during March 2008 to February 2009 in morning hours. The samples were taken in borosil glass bottles of $300 \mathrm{ml}$ and plastic cans of $1.0 \mathrm{~L}$ from each location. The collection and analysis of water samples was done using standard methods with the help of Welch (1948), Trivedi and Goel (1986), APHA (1998) and Khanna and Bhutiani (2003) for physico-chemical parameters.

Sampling stations -For the present study a total of four sampling stations were selected for physicochemical studies of the reservoir i.e.

SITE I: Southern shore of the reservoir.

SITE II: Eastern shore of the reservoir

\section{Results and Discussion}

The results and data collected on physico-chemical parameters during the present investigation are presented in Table 1 and 2. Temperature can be 
described as a condition that is responsible for the transfer of heat within bodies. Temperature contributes to the solubility of $\mathrm{H}_{2}, \mathrm{~N}_{2}, \mathrm{CO}_{2}$ and $\mathrm{O}_{2}$ which play vital roles in aquatic ecosystems (Gillooly et al. 2002). In the present study temperature was reported maximum of $31.44^{\circ} \mathrm{C}$ in the month of July and minimum of $21^{\circ} \mathrm{C}$ in the month of January. Das (1989) expressed that the lakes which do not come under oligotrophic and eutrophic status and fall intermediate between oligotrophic and eutrophic can be termed as mesotrophic. Edmondson et al. (1956) emphasized the importance of transparency in determining the lake trophic status. Sharma (1980) has also attempted to classify water bodies on the basis of water clarity values. Transparency was reported maximum of $9.12 \mathrm{~cm}$ in the month of June and minimum of $3.98 \mathrm{~cm}$ in the month of December. Turbidity was reported maximum of 28 JTU in the month of August and minimum of 13 JTU in the month of December. TDS was reported maximum of $220 \mathrm{mg} / \mathrm{l}$ in the month of July and minimum of $110 \mathrm{mg} / \mathrm{l}$ in the month of February.The $\mathrm{pH}$ of pond water in general showed an alkaline tendency during all the months (Table 1). The maximum $\mathrm{pH}$ noticed in the study period was 8.35 in the month of May and the minimum $\mathrm{pH}$ noticed was 7.12 in the month of October. $\mathrm{pH}$ showed a negative correlation with temperature and Free $\mathrm{CO}_{2}$ (Table 3). Low $\mathrm{pH}$ also interferes with oxygen uptake, and
$\mathrm{pH}$ outside range of 4.00 to 10.00 can kill fish (Mathew, 1998).The maximum free carbon dioxide was observed $(3.60 \mathrm{mg} / \mathrm{l})$ in monsoon season because of the slightly higher temperature of water and higher turbidity, which lowers the rate of photosynthesis and thus the dissolved oxygen. However, it was minimum $(1.0 \mathrm{mg} / \mathrm{l})$ in the winter season when the temperature of water decreased and also the turbidity was almost nil.Ray et al. (1966) have reported that the Ganga river contains maximum free carbon dioxide (free $\mathrm{CO}_{2}$ ) in the rainy season in Allahabad also recorded the maximum free carbon dioxide in Yamuna during monsoon season at Allahabad. The free carbon dioxide is released during the decomposition of certain substances and because of respiration of the prevailing living organisms. Since higher temperature regulates the decomposition of organic substances and also the respiration of the living biota, a direct relationship existed between free carbon dioxide and water temperature.The total hardness during the overall study ranged with maximum $(131.04 \mathrm{mg} / \mathrm{l})$ in Monsoon season and minimum $(111.98 \mathrm{mg} / \mathrm{l})$ in winter season. The phosphate and nitrate are mostly decomposition products of organic waste/matter. Hardness in water is mainly because of presence of calcium and magnesium in the water and its source may be industrial, domestic or commercial waste and sewage but one of the main sources of calcium is natural rocks of that area.

Table 1 - Monthly variation in Physico-chemical parameters of sampling Site I

\begin{tabular}{|c|c|c|c|c|c|c|c|c|c|c|c|c|}
\hline Months & $\begin{array}{c}\text { Temp } \\
\left({ }^{\circ} \mathrm{C}\right)\end{array}$ & $\begin{array}{c}\text { Trans } \\
\text { paren } \\
\text { cy } \\
(\mathbf{c m})\end{array}$ & $\begin{array}{c}\text { Turbidity } \\
\text { (JTU) }\end{array}$ & $\begin{array}{c}\text { TDS } \\
(\mathrm{mg} / \mathrm{l})\end{array}$ & pH & $\begin{array}{c}\text { Free } \\
\mathrm{CO}_{2} \\
(\mathrm{mg} / \mathrm{l})\end{array}$ & $\begin{array}{c}\text { Total } \\
\text { Hardness } \\
(\mathrm{mg} / \mathrm{l})\end{array}$ & $\begin{array}{c}\text { Ca } \\
\text { Hardness } \\
(\mathrm{mg} / \mathrm{l})\end{array}$ & $\begin{array}{c}\text { Mg } \\
\text { Hardness } \\
(\mathrm{mg} / \mathrm{l})\end{array}$ & $\begin{array}{c}\text { DO } \\
(\mathrm{mg} / \mathrm{l})\end{array}$ & $\begin{array}{c}\text { BOD } \\
(\mathrm{mg} / \mathrm{l})\end{array}$ & $\begin{array}{r}\text { COD } \\
(\mathrm{mg} / \mathrm{l})\end{array}$ \\
\hline October & 30.1 & 4.24 & 15 & 179 & 7.12 & 2.12 & 120.15 & 27.4 & 11.4 & 7.0 & 2.78 & 9.1 \\
\hline November & 22.5 & 8.02 & 18 & 187 & 7.98 & 1.01 & 115.00 & 26.5 & 10.9 & 7.98 & 2.50 & 9.0 \\
\hline December & 21.4 & 3.98 & 12 & 130 & 7.85 & 1.00 & 114.02 & 26.1 & 12.50 & 8.21 & 1.99 & 9.2 \\
\hline January & 21.0 & 5.87 & 16 & 128 & 8.01 & 1.30 & 118.00 & 25.7 & 13.29 & 7.88 & 2.01 & 9.5 \\
\hline February & 22.6 & 5.23 & 15 & 154 & 7.88 & 1.28 & 120.21 & 26.2 & 14.15 & 6.98 & 2.98 & 9.9 \\
\hline March & 24.5 & 6.56 & 19 & 125 & 7.54 & 1.43 & 123.00 & 29.7 & 15.64 & 6.04 & 3.51 & 10.3 \\
\hline April & 26.4 & 7.12 & 22 & 178 & 7.64 & 2.23 & 128.00 & 30.4 & 16.10 & 6.78 & 2.88 & 10.5 \\
\hline May & 29.5 & 7.56 & 27 & 142 & 7.36 & 3.60 & 131.04 & 33.5 & 22.3 & 6.98 & 2.78 & 10.7 \\
\hline June & 30.2 & 6.40 & 24 & 186 & 8.06 & 2.60 & 127.25 & 34.8 & 23.8 & 7.56 & 2.15 & 11.1 \\
\hline July & 29.8 & 5.40 & 26 & 195 & 8.09 & 2.30 & 111.98 & 28.4 & 10.80 & 7.54 & 2.10 & 10.6 \\
\hline August & 26.9 & 8.70 & 28 & 175 & 8.04 & 2.45 & 119.58 & 27.1 & 9.78 & 8.12 & 1.98 & 9.7 \\
\hline September & 27.1 & 7.48 & 24 & 138 & 7.99 & 2.23 & 121.21 & 25.9 & 10.09 & 7.11 & 2.01 & 9.1 \\
\hline $\begin{array}{c}\text { Average } \\
\pm \mathrm{SD}\end{array}$ & $\begin{array}{c}26 \\
\pm 3.51\end{array}$ & $\begin{array}{c}6.38 \\
\pm 1.48\end{array}$ & $\begin{array}{c}20.5 \\
\pm 5.37\end{array}$ & $\begin{array}{l}159.75 \\
\pm 26.17\end{array}$ & $\begin{array}{c}7.80 \\
\pm 0.31\end{array}$ & $\begin{array}{c}1.96 \\
\pm 0.78\end{array}$ & $\begin{array}{c}120.79 \\
\pm 5.81\end{array}$ & $\begin{array}{l}28.48 \\
\pm 3.05\end{array}$ & $\begin{array}{l}14.23 \\
\pm 4.61\end{array}$ & $\begin{array}{c}7.35 \\
\pm 0.65\end{array}$ & $\begin{array}{c}2.47 \\
\pm 0.51\end{array}$ & $\begin{array}{c}9.89 \\
\pm 0.73\end{array}$ \\
\hline
\end{tabular}

Environment Conservation Journal 
Physico-chemical study of Moghat Reservoir

Table 2: Monthly variation in Physico-chemical parameters of sampling Site II

\begin{tabular}{|c|c|c|c|c|c|c|c|c|c|c|c|c|}
\hline Months & $\begin{array}{c}\text { Temp } \\
\left({ }^{\mathbf{0}} \mathbf{C}\right)\end{array}$ & $\begin{array}{c}\text { Trans } \\
\mathbf{p a r e n} \\
\mathbf{c y} \\
(\mathbf{c m})\end{array}$ & $\begin{array}{c}\text { Turbidity } \\
(\mathbf{J T U})\end{array}$ & $\begin{array}{c}\text { TDS } \\
(\mathbf{m g} / \mathbf{l})\end{array}$ & $\mathbf{p H}$ & $\begin{array}{c}\text { Free } \\
\mathbf{C O} \mathbf{2} \\
(\mathbf{m g} / \mathbf{l})\end{array}$ & $\begin{array}{c}\text { Total } \\
\text { Hardness } \\
(\mathbf{m g} / \mathbf{l})\end{array}$ & $\begin{array}{c}\text { Ca } \\
\text { Hardness } \\
(\mathbf{m g} / \mathbf{l})\end{array}$ & $\begin{array}{c}\text { Mg } \\
\text { Hardness } \\
(\mathbf{m g} / \mathbf{l})\end{array}$ & $\begin{array}{c}\text { DO } \\
(\mathbf{m g} / \mathbf{l})\end{array}$ & $\begin{array}{c}\text { BOD } \\
(\mathbf{m g} / \mathbf{l})\end{array}$ & $\begin{array}{c}\mathbf{C O D} \\
(\mathbf{m g} / \mathbf{l})\end{array}$ \\
\hline October & 22.50 & 5.54 & 14 & 180 & 8.26 & 1.57 & 119.21 & 22.54 & 15.45 & 6.98 & 2.45 & 9.9 \\
\hline November & 24.65 & 4.98 & 13 & 169 & 8.24 & 1.90 & 121.12 & 26.12 & 10.94 & 7.01 & 2.22 & 9.3 \\
\hline December & 26.54 & 5.04 & 13 & 163 & 8.27 & 1.24 & 124.50 & 24.45 & 11.54 & 7.24 & 1.98 & 10.1 \\
\hline January & 27.85 & 6.78 & 16 & 129 & 8.24 & 1.44 & 118.00 & 25.54 & 13.43 & 8.58 & 0.98 & 10.3 \\
\hline February & 27.12 & 5.98 & 14 & 110 & 8.25 & 1.99 & 117.58 & 23.02 & 16.54 & 8.01 & 1.01 & 10.7 \\
\hline March & 26.45 & 4.89 & 15 & 134 & 8.27 & 2.01 & 126.54 & 27.87 & 12.41 & 7.98 & 2.01 & 11.1 \\
\hline April & 28.87 & 5.12 & 15 & 159 & 8.29 & 1.89 & 127.44 & 26.54 & 15.32 & 7.56 & 2.24 & 11.5 \\
\hline May & 29.32 & 8.02 & 18 & 187 & 8.35 & 2.87 & 121.21 & 24.56 & 14.21 & 7.45 & 2.56 & 11.6 \\
\hline June & 30.25 & 9.12 & 21 & 219 & 8.30 & 2.89 & 131.02 & 27.88 & 13.21 & 7.86 & 2.87 & 12.3 \\
\hline July & 31.44 & 8.78 & 22 & 220 & 7.51 & 2.77 & 129.87 & 26.54 & 14.22 & 7.65 & 2.55 & 11.9 \\
\hline August & 28.57 & 7.89 & 20 & 192 & 7.64 & 2.99 & 124.56 & 21.25 & 16.45 & 7.02 & 1.65 & 11.3 \\
\hline September & 24.58 & 7.56 & 17 & 186 & 8.24 & 2.48 & 119.20 & 24.65 & 13.24 & 6.98 & 3.01 & 10.8 \\
\hline Average & 27.35 & 6.64 & 16.50 & 170.67 & 8.16 & 2.17 & 123.35 & 25.08 & 13.91 & 7.53 & 2.13 & 10.90 \\
\pm SD & \pm 2.58 & \pm 1.58 & \pm 3.12 & \pm 34.08 & \pm 0.27 & \pm 0.61 & \pm 4.64 & \pm 2.08 & \pm 1.80 & \pm 0.51 & \pm 0.65 & \pm 0.89 \\
\hline
\end{tabular}

Table: 3 Pearson correlation coefficient between physico-chemical parameters of Moghat Reservoir

\begin{tabular}{|c|c|c|c|c|c|c|c|c|c|c|c|}
\hline & Temperature & Transperancy & Turbidity & TDS & $\mathrm{pH}$ & $\begin{array}{l}\text { Free } \\
\mathrm{CO}_{2} \\
\end{array}$ & $\begin{array}{l}\text { Total } \\
\text { Hardness }\end{array}$ & $\begin{array}{l}\mathrm{Ca} \\
\text { Hardness }\end{array}$ & $\begin{array}{l}\mathrm{Mg} \\
\text { Hardness }\end{array}$ & DO & BOD \\
\hline \multicolumn{12}{|l|}{ Temperature } \\
\hline Transperancy & 0.63 & & & & & & & & & & \\
\hline Turbidity & 0.74 & 0.93 & & & & & & & & & \\
\hline TDS & 0.34 & 0.69 & 0.73 & & & & & & & & \\
\hline $\mathrm{pH}$ & -0.44 & -0.47 & -0.64 & 0.45 & & & & & & & \\
\hline Free $\mathrm{CO}_{2}$ & 0.57 & 0.82 & 0.85 & 0.66 & -0.47 & & & & & & \\
\hline $\begin{array}{l}\text { Total } \\
\text { Hardness }\end{array}$ & 0.64 & 0.32 & 0.56 & 0.57 & -0.36 & 0.42 & & & & & \\
\hline Ca Hardness & 0.34 & 0.02 & 0.14 & 0.1 & 0.23 & 0.02 & 0.58 & & & & \\
\hline Mg Hardness & 0.19 & 0.24 & 0.26 & -0.05 & -0.32 & 0.29 & -0.13 & -0.59 & & & \\
\hline DO & 0.45 & 0.08 & 0.1 & -0.47 & 0.15 & -0.15 & 0.05 & 0.44 & 0.04 & & \\
\hline BOD & -0.02 & 0.35 & 0.35 & 0.78 & 0.03 & 0.44 & 0.43 & 0.33 & -0.27 & -0.53 & \\
\hline COD & 0.82 & 0.7 & 0.81 & 0.48 & -0.31 & 0.75 & 0.68 & 0.32 & 0.34 & 0.28 & 0.33 \\
\hline
\end{tabular}

During the study the maximum value of calcium aquatic life in order for aerobic species to be able to and magnesium observed was $(34.8 \mathrm{mg} / \mathrm{l})$ and $(23.8$ survive and carry out their ecological functions. $\mathrm{mg} / \mathrm{l})$ respectively and the minimum value observed Lack of DO can lead to anaerobic decomposition of for calcium and magnesium was $(25.7 \mathrm{mg} / \mathrm{l})$ and organic matter, resulting in unpleasant odour that is $(9.78 \mathrm{mg} / \mathrm{l})$.Oxygen occurs naturally in the indicative of formation of hydrogen sulphide and atmosphere as gas and is also produced via ammonium (Schindler, 1981). The concentration of photosynthesis. Oxygen is not readily soluble in DO during present study was recorded with the water, and its solubility relies on temperature, maximum of $8.21 \mathrm{mg} / \mathrm{l}$ in the month of December salinity and atmospheric pressure (DWAF, 1996). and minimum of $6.04 \mathrm{mg} / \mathrm{l}$ in the month of March. Dissolved oxygen (DO) is critical for sustenance of D.O was found correlated positively correlated with 
transperancy and $\mathrm{pH}$ (table 3). BOD is the measure of degradable organic matter present in a water sample and is defined as the amount of oxygen required by microorganisms in stabilizing biologically degradable organic matter under aerobic conditions. BOD of the pond water during the study varied from minimum of $.98 \mathrm{mg} / \mathrm{l}$ in the month of January to the maximum of $3.51 \mathrm{mg} / \mathrm{l}$ in the month of March. BOD was found significantly negatively correlated with $\mathrm{Mg}$. hardness and D.O. Calcium is one of the most abundant substances in natural water. The quantity of $\mathrm{Ca}$ in natural water generally varies from $10-100 \mathrm{mgL}-1$ depending on the type of rocks (Trivedy and Goel, 1986). Magnesium occurs in all kinds of natural water with calcium, but the concentration remains generally lower than that of calcium. Calcium and magnesium showed significant positive correlation with temperature.

\section{References}

APHA (American Public Health Association), 1998. Standard method for examination of water and wastewater, 20th edition, Washington, DC, USA, P. 4.66-4.69.

Das, S.M. 1989. In: Handbook of Limnology and water pollution. South Asian Publishers, New Delhi 1-174
DWAF - (Department of Water Affairs and Forestry) 1996a. South African water quality guidelines. Volume 1: Domestic use. Department of Water Affairs and Forestry. Pretoria, South Africa

Gillooly J.F., Charnov E.L., West G.B., Savage V.M. and Brown J.H. 2002. Effects of size and temperature on developmental time. Nature ,417:70-73.

Khanna,D.R. and Bhutiani,R. 2003. Limnological characteristic of the river Ganga at Haridwar (Uttaranchal), U.P.J.Zool., Vol. 23(3): 179-183.

Ray, P., Singh, S.B. and Sehgal, K.L. 1966: A study of some aspects of the river Ganga and Jamuna at Allahabad (U.P.) in 1958-59. Proc. Nat. Acad. Sci. India, 36 B(3): 235-464.

Schindler D.W. 1981. Interrelationships between the cycles of elements in freshwater ecosystems: some perspectives of the major biogeochemical cycles. In: Perspectives of the major biogeochemical cycles. Likens G.E. (ed). New York, USA, Chapter 7, pp 113-123

Trivedy, R. K. and P. K. Goel 1986. Chemical and biological methods for water pollution studies. Environmental Publications. Karad, 1- 250.

Welch, P.S. 1948. Limnological Methods, the Blakiston. Co. Philadelphia, 1-381. 